\title{
Do pre-dispersal insect seed predators contribute to maintaining tropical forest plant diversity?
}

Article

Accepted Version

Gripenberg, S. (2018) Do pre-dispersal insect seed predators contribute to maintaining tropical forest plant diversity?

Biotropica, 50 (6). pp. 839-845. ISSN 1744-7429 doi: https://doi.org/10.1111/btp.12602 Available at https://centaur.reading.ac.uk/80229/

It is advisable to refer to the publisher's version if you intend to cite from the work. See Guidance on citing.

To link to this article DOI: http://dx.doi.org/10.1111/btp.12602

Publisher: Association for Tropical Biology and Conservation

All outputs in CentAUR are protected by Intellectual Property Rights law, including copyright law. Copyright and IPR is retained by the creators or other copyright holders. Terms and conditions for use of this material are defined in the End User Agreement.

www.reading.ac.uk/centaur

\section{CentAUR}


Central Archive at the University of Reading

Reading's research outputs online 
1

2 LRH: Gripenberg

3

$4 \quad$ RRH: Pre-dispersal Seed Predation by Insects

5

6

7

8

9 Do pre-dispersal insect seed predators contribute to maintaining tropical forest plant

10 diversity?

11

12

13 Sofia Gripenberg

14

15 Department of Zoology

16 OX1 3PS

17 University of Oxford

18 Oxford

19 UK

20

21 E-mail: sofia.gripenberg@zoo.ox.ac.uk

22

23

24 Received___ ; revision accepted___. (Biotropica will fill in the dates.) 


\section{Abstract}

26 No abstract provided as manuscript is intended as a Commentary

27

28

29 Key words: density-dependence; fruit abscission; host specificity; Janzen-Connell hypothesis;

30 plant reproduction; seed predation 
32 observed in many tropical forests is a key aim in tropical ecology (e.g., Wright 2002, Leigh et al.

33 2004). What allows hundreds of tree species (Valencia et al. 1994) and a substantial number of

34 liana species (Schnitzer et al. 2012) to co-occur locally in these forests? Among the many and

35 mutually non-exclusive mechanisms proposed (Wright 2002), the role of natural enemies has

36 received particular attention.

37 According to the Janzen-Connell hypothesis (Janzen 1970, Connell 1971), the

38 coexistence - and the consequent high alpha diversity - of plant species in tropical forests is

39 promoted by specialised natural enemies such as pathogens and insect herbivores that cause

40 density- and/or distance-dependent patterns of plant survival. By making individuals more prone

41 to enemy-attack when surrounded by conspecifics, plants will tend to fare better when

42 conspecific density in the neighbourhood is low, thereby enhancing diversity at the community

43 level. Many studies have documented distance- and density-dependence in the survival of seeds

44 and seedlings in line with these predictions (for a recent meta-analysis, see Comita et al. 2014).

45 Although it is often not clear what types of enemies contribute to observed patterns of plant

46 mortality, data have slowly started to accumulate (e.g., Bell et al. 2006, Mangan et al. 2010,

47 Bagchi et al. 2014, Fricke et al. 2014).

48 The current literature on the role of enemies in plant diversity maintenance is dominated

49 by studies assessing conspecific density and distance effects at relatively small spatial scales and

50 focusing on seedlings or seeds that have already dispersed from the mother plant (e.g., Harms et

51 al. 2000, Bagchi et al. 2014). However, as noted by Gillett (1962), enemy-inflicted plant

52 mortality with implications for diversity can also involve pests attacking seeds that are still

53 attached to the mother plant. This idea was reiterated by Janzen (1970), who suggested that host- 
54 specific pre-dispersal enemies can enhance diversity if they destroy a particularly large

55 proportion of the seed crop where multiple reproductive conspecifics grow close to each other.

56 However, in an alternative line of reasoning (see Fig. 2 and 3 in Janzen's publication), Janzen

57 also illustrates how pre-dispersal enemies - regardless of their specificity - may in fact have the

58 potential to erode plant diversity. According to this argument, the reduction in seed crop sizes

59 caused by pre-dispersal enemies will truncate seed dispersal kernels, since with fewer seeds the

60 probability of long-distance dispersal will decrease. This will inevitably decrease the distance

61 between conspecific adults unless offset by foraging patterns of post-dispersal enemies and/or

62 negative density-dependence acting across larger spatial scales. Almost 50 years on, while some

63 aspects of Janzen's predictions have been hugely influential on empirical research, the pre-

64 dispersal element has been largely neglected. As I argue below, pre-dispersal insect seed

65 predators fulfil several criteria for being important diversity-enhancing plant enemies; yet they

66 have been summarily ignored by ecologists interested in Janzen-Connell effects. Here I propose

67 a research agenda for rectifying this.

69 CURRENT EVIDENCE. - Pre-dispersal insect seed predators have the potential to influence the 70 ecological and evolutionary dynamics of their hosts (Kolb et al. 2007). Several lines of evidence

71 suggest that they may also be important for plant diversity maintenance in tropical forests:

A large proportion of plant species are attacked by pre-dispersal seed predators and the

73 number of seeds killed can be substantial. - Since Janzen's pioneering work on bruchid beetles

74 in Costa Rica (1980), several studies have assessed patterns of insect seed predation in tropical

75 forest plant communities in different parts of the world (Table 1). The results from these studies

76 suggest that insect seed predation is common: a substantial proportion of surveyed plant species 
77 were observed to be attacked by at least one species of insect seed predator, many of which are

78 likely to have attacked the seeds while they were still attached to the mother plant. Only some of

79 the studies in Table 1 attempted to quantify the proportion of seeds falling victim to predators

80 through seed dissection or experimental manipulations. Where assessed, seed predation rates

81 varied widely among species. While some authors (e.g., Ctvrtecka et al. 2014) have concluded

82 that their focal seed predator taxa are too rare to contribute to plant diversity maintenance, care

83 should be taken in extrapolating such conclusions to other contexts and systems. It is worth

84 noting that seed predation rates obtained through rearing or visual examination of seeds could

85 severely underestimate the true impact of insect seed predators (Andersen 1988), for example

86 where seed predators do not leave any clear feeding marks on their hosts. True seed predation

87 rates are therefore likely to be higher than those reported in the literature.

88 Seed predators show remarkable levels of host-specificity. - For the Janzen-Connell

89 mechanism to contribute to diversity maintenance, enemies need to be relatively specialised

90 (Sedio \& Ostling 2013, Stump \& Chesson 2015). Several studies have assessed host specificity

91 of internally feeding insect seed predators (e.g., Janzen 1980, Ctvrtecka et al. 2014). An overall

92 pattern to emerge is that these insects typically feed on one or a few closely related species and

93 tend to be more specialised than other feeding guilds (Novotny et al. 2010; but see Sam et al.

94 2017). Less is known about the specificity of other guilds of seed-eating insects (e.g. sap-suckers

95 and external feeders), but there is no doubt that at least the internally feeding seed predators are

96 good candidate enemies in the context of plant diversity maintenance.

$97 \quad$ There is high potential for landscape-level density-dependence in pre-dispersal seed

98 predation rates. - Studies testing for density-dependence of insect seed predation and/or seed

99 survival over large spatial scales remain scarce (but see e.g. Visser et al. 2011). In one of the few 
100 studies involving pre-dispersal seed predators, Jones and Comita (2011) assessed premature fruit

101 abscission caused by a hymenopteran seed predator on Jacaranda copaia in the 50-ha forest

102 dynamics plot on Barro Colorado Island (Panama). In line with Janzen's predictions, seed

103 predation rates increased with increasing fruit densities. Nevertheless, this increase was not large

104 enough to cancel out the positively density-dependent fruit set (a likely result of pollination

105 success being highest in parts of the forest where there are many fruiting conspecifics). It is

106 plausible that landscape-level density dependence in seed predation rates might occur in other

107 species as well: The patchy distribution of host plants across the forest landscape (Condit et al.

108 2000) may impose spatial structure in insect abundances through behavioural responses of

109 insects to local resource abundances. Studies of host-specific folivorous insect herbivores

110 associated with trees in temperate regions have shown that the degree of host tree isolation can

111 be an important determinant of landscape-level patterns of insect distribution (e.g., Gripenberg et

112 al. 2008, Tack et al. 2010). Spatially-structured populations driven by - and in turn potentially

113 influencing - tree distributions may be particularly prevalent in species-rich tropical forests,

114 since the low abundance of individual tree species will make their distributions patchy. Since the

115 area as well as the isolation of habitat patches is key to influencing incidence and abundance in

116 spatially-structured populations (e.g. Hanski 1994), it seems possible that any positive effects of

117 landscape-level tree densities on seed predator incidence, abundance, and attack rates may be

118 particularly pronounced in relatively small-sized tree species, where the small size of host

119 individuals could lead to higher patch-level extinction rates.

120

121 WhAT NEXT? - Pre-dispersal seed predators cannot be dismissed as potentially important agents

122 of diversity maintenance, but we are still a long way from answering the question of whether 
123 they do indeed facilitate coexistence of plant species in tropical forests. The logistical challenges

124 of studying seed predation in the canopy are substantial and community-level manipulations of

125 pre-dispersal enemies analogous to those that have been done for post-dispersal enemies (Bagchi

126 et al. 2014) will be unfeasible. To answer the question of whether pre-dispersal insect seed

127 predators promote the coexistence of plant species in tropical forests a combination of multiple

128 approaches (experiments, field observations, modelling) will therefore be needed. Below I

129 identify a few starting points for moving the research field forward:

130 First, manipulative experiments excluding seed predators from selected plant individuals

131 could yield important insights into the ecological role of pre-dispersal insect seed predators in

132 tropical forests. These experiments could focus on single plant species, although it would be

133 helpful to conduct experiments across a range of species to assess the generality of patterns

134 observed. In addition to allowing us to quantify levels of seed predation, manipulative

135 experiments could verify that pre-dispersal insect seed predators are indeed causing additional

136 seed mortality: If, as has been suggested (Ghazoul \& Satake 2009), trees sometimes initiate more

137 seeds than could possibly be brought to maturity and then selectively abort insect-infested seeds,

138 seemingly high levels of seed infestation rates recorded in observational studies may have little

139 effect on plant fitness. In the context of plant diversity maintenance, it would be particularly

140 interesting to assess the effects of seed predator exclusion on seed dispersal kernels and seedling

141 recruitment curves (see Fig. 2 and 3 in Janzen, 1970), and to use sensitivity analyses to

142 determine what levels of pre-dispersal seed predation would influence diversity through

143 alternations in dispersal kernels. While experiments on single species do not answer the question

144 of what happens in the wider community following seed predator exclusion, the community-

145 level implications could be assessed by inputting results of individual species experiments to 
146 models that predict community patterns (e.g. changes in species abundance distributions through

147 early ontogeny) and exploring how community-wide patterns deviate from the predictions based

148 on these models. Conducting manipulative experiments at the whole-tree scale does not come

149 without challenges, but excluding pre-dispersal seed predators from selected tree individuals

150 using insecticides (Louda 1982) or bagging (Nakagawa et al. 2005) - combined with appropriate

151 control procedures - might be feasible for selected understorey tree species, for species

152 producing seeds in discrete clusters (e.g. palms), or for species that can be accessed through one

153 of the canopy cranes available for canopy research (e.g. Parker et al. 1992).

154 Second, further observational studies assessing spatial and temporal patterns of pre-dispersal 155 seed predation are needed before generalisations about 'typical' responses of seed predators to

156 variations in resource abundances can be made. A primary aim of these studies would be to test

157 if the positive landscape-level density-dependence in seed predation hypothesised by Janzen

158 (which could serve as a stabilising factor promoting species coexistence) occurs, or if seed

159 predators are more typically satiated under high seed abundances. Given the potential scale-

160 dependence of density-effects (Schupp 1992, Xiao et al. 2017), sampling protocols should be

161 designed to allow testing for density-responses across multiple spatial scales. Since temporal

162 variation in seed predation rates may also have implications for coexistence (Chesson 1985),

163 studies should ideally be conducted over several fruiting seasons. The seed and fruit monitoring

164 schemes established at some permanent forest dynamics plots (e.g. Anderson-Teixeira et al.

165 2015) could provide opportunities for assessing long-term temporal variation in seed predation

166 rates if combined with protocols for scoring insect damage. Ideally, observational studies on

167 density-responses of seed predators would be followed by modelling studies to assess whether

168 observed density responses (which may be positive at some spatial scales, negative at other) are 
169 sufficient to act as a mechanism regulating plant population growth. One challenge is that studies

170 need to be conducted over large spatial scales given the potentially high dispersal ability of

171 insect seed predators. For many species, existing forest dynamics plots may be too small for this

172 purpose. Newly developed remote sensing techniques might prove useful when identifying

173 landscape-level variation in conspecific densities of canopy trees over larger areas (see Jansen $e t$

174 al. 2008). Another challenge in quantifying pre-dispersal seed predation rates through

175 observations is removal of seeds from the canopy by dispersers. Obtaining accurate estimates

176 might still be feasible for species with cupules or other structures that are not removed by seed

177 dispersers.

178 Third, although the focus of this commentary is on pre-dispersal seed predation, it is

179 important to remember that plant performance with potential implications for coexistence is

180 likely to be the result of multiple processes. We know little about the role of other taxa

181 influencing pre-dispersal seed mortality, and even less about the ways in which they potentially

182 enhance or hinder the influence of each other. There is room for both field-based and theoretical

183 work assessing the combined effects of processes such as pollination, seed dispersal, and

184 mortality caused by various groups of pre- and post-dispersal enemies on plant diversity, as well

185 as studies integrating mortality processes at different stages of the plant life cycle (Green \&

186 Harms 2018). For example, it is known that feeding by insects in the canopy can affect the

187 vigour of seedlings, and therefore the plant's tolerance to hazards at later stages (Sousa et al.

188 2003, Bonal et al. 2007). If we focus our efforts too narrowly on one enemy group and/or one

189 specific life stage - as is often the case in work done to date - there is a risk that we miss or

190 greatly underappreciate crucially important interactions. 
192 CONCLUSIONS - There is ample scope for interesting work on the diversity-enhancing effects of

193 pre-dispersal enemies paralleling work that has been done on post-dispersal enemies. This work

194 would not only be of academic interest but also of potential importance in the context of current

195 environmental changes. With fruiting patterns possibly changing following climate change (see

196 e.g. Wright \& Calderon 2006), this could lead to disruptions in the pre-dispersal seed predation

197 process. Unless we know the ecological role of this enemy group, we don't know what the

198 consequences are going to be for the diversity of plants in tropical forests.

\section{ACKNOWLEDGMENTS}

201 I thank Joe Wright, Owen Lewis and Yves Basset for helpful discussions and for comments on

202 an earlier draft on this text. Feedback by Andy Jones, Noelle Beckman, Robert Bagchi and an

203 anonymous reviewer helped improve the text. Some of the ideas presented in this essay were

204 developed during field work on Barro Colorado Island funded by the Academy of Finland

205 (project number 138299), the Royal Society (University Research Fellowship and RG130393),

206 and GACR (16-20825S).

\section{LITERATURE CITED}

209 ANDERSEN, A. N. 1988. Insect seed predators may cause far greater losses than they appear to.

$210 \quad$ Oikos 52: 337-340.

211 Anderson-Teixeira, K. J., S. J. Davies, A. C. Bennett, E. B. GonZALEZ-Akre, H. C. Muller-

212 Landau, S. Joseph Wright, K. Abu Salim, A. M. Almeyda Zambrano, A. Alonso, J.

213 L. Baltzer, Y. Basset, N. A. Bourg, E. N. BroAdBent, W. Y. Brockelman, S.

214 Bunyavejchewin, D. F. R. P. Burslem, N. Butt, M. CaO, D. Cardenas, G. B. 
Chuyong, K. Clay, S. Cordell, H. S. Dattaraja, X. Deng, M. Detto, X. Du, A. P. Giardina, G. S. Gilbert, N. Gunatilleke, S. Gunatilleke, Z. Hao, W. W. Hargrove, T. B. Hart, B. C. H. HaU, F. He, F. M. Hoffman, R. W. Howe, S. P. Hubbell, F. M. InMan-NARAhari, P. A. Jansen, M. JiAng, D. J. Johnson, M. KANZAKi,

A. R. Kassim, D. Kenfack, S. Kibet, M. F. Kinnaird, L. Korte, K. Kral, J. Kumar, A. J. Larson, Y. Li, X. Li, S. LiU, S. K. Y. LuM, J. A. LutZ, K. Ma, D. M. Maddalena, J.-R. Makana, Y. Malhi, T. Marthews, R. Mat Serudin, S. M. McMahon, W. J. McShea, H. R. Memiaghe, X. Mi, T. Mizuno, M. Morecroft, J. A. Myers, V. Novotny, A. A. De Oliveira, P. S. Ong, D. A. Orwig, R. Ostertag, J. Den Ouden, G. G. PARker, R. P.

Phillips, L. Sack, M. N. Sainge, W. Sang, K. SRI-ngernyuang, R. Sukumar, I. F. Sun, W. Sungpalee, H. S. Suresh, S. Tan, S. C. Thomas, D. W. Thomas, J. Thompson, B. L. Turner, M. Uriarte, R. Valencia, M. I. Vallejo, A. Vicentini, T. VrŠKa, X. Wang, X. WANG, G. Weiblen, A. Wolf, H. Xu, S. YAP, AND J. ZimMERMAn. 2015. CTFSForestGEO: a worldwide network monitoring forests in an era of global change. Global Change Biology 21: 528-549.

BAGChi, R., R. E. Gallery, S. GriPENBERG, S. J. GuRr, L. NARAyAn, C. E. AdDis, R. P. FRECKLETON, AND O. T. LEWIS. 2014. Pathogens and insect herbivores drive rainforest plant diversity and composition. Nature 506: 85-88.

234 Basset, Y., C. Dahl, R. Ctvrtecka, S. Gripenberg, O. T. Lewis, S. T. Segar, H. Barrios, J. W. Brown, S. Bunyavejchewin, B. A. Butcher, A. I. Cognato, S. Davies, O. Kaman, P. Klimes, M. KNizeK, S. E. Miller, G. E. Morse, V. Novotny, N. 

WRIGHT. 2018. A cross-continental comparison of assemblages of seed- and fruit-feeding insects in tropical rain forests: Faunal composition and rates of attack. J. Biogeogr., in

BeCKMAN, N. G., AND H. C. MULLER-LANDAU. 2011. Linking fruit traits to variation in predispersal vertebrate seed predation, insect seed predation, and pathogen attack.

Bell, T., R. P. FRECKLETON, AND O. T. LEWIS. 2006. Plant pathogens drive density-dependent Ecology 92: 2131-2140.

BonAL, R., A. MunOZ, AND M. DiAZ. 2007. Satiation of predispersal seed predators: the importance of considering both plant and seed levels. Evol. Ecol. 21:367-380.

CHESSON, P. L. 1985. Coexistence of competitors in spatially and temporally varying environments: a look at the combined effects of different sorts of variability. Theoretical Population Biology 28: 263-287.

Comita, L. S., S. A. QueEnborough, S. J. Murphy, J. L. Eck, K. Xu, M. Krishnadas, N. BECKMAN, AND Y. ZHU. 2014. Testing predictions of the Janzen-Connell hypothesis: a meta- analysis of experimental evidence for distance- and density- dependent seed and seedling survival. J. Ecol. 102: 845-856.

Condit, R., P. S. Ashton, P. Baker, S. Bunyavejchewin, S. Gunatilleke, N. Gunatilleke, S. P. Hubbell, R. B. Foster, A. Itoh, J. V. LaFrankie, H. S. Lee, E. Losos, N. MANOKARAN, R. SUKUMAR, AND T. YAMAKURA. 2000. Spatial patterns in the distribution of tropical tree species. Science 288: 1414-1418. 
260 ConNelL, J. H. 1971. On the role of natural enemies in preventing competitive exclusion in some marine animals and in rain forest trees. In P. J. Den Boer and G. R. Gradwell (Ed.). Dynamics of populations, pp. 298-312. PUDOC, Wageningen.

263 Ctvrtecka, R., K. Sam, E. Brus, G. D. Weiblen, And V. Novotny. 2014. Frugivorous weevils are too rare to cause Janzen-Connell effects in New Guinea lowland rain forest. J. Trop. Ecol. 30: 521-535.

266 FricKe, E. C., J. J. TewKSBURY, AND H. S. Rogers. 2014. Multiple natural enemies cause distance-dependent mortality at the seed-to-seedling transition. Ecol. Lett. 17: 593-598.

268 GHAZOUL, J., AND A. SATAKE. 2009. Nonviable seed set enhances plant fitness: the sacrificial sibling hypothesis. Ecology 90: 369-377.

270 GREEN, P. T. AND K. E. HARMS. 2018. The causes of disproportionate non-random mortality among life-cycle stages. Ecology 99: 36-46.

272 GREIG, N. 1993. Predispersal seed predation on five Piper species in tropical rainforest.

273 Oecologia 93: 412-420.

274 Gripenberg, S., O. OvaSkAinen, E. Morrien, AND T. Roslin. 2008. Spatial population

275 structure of a specialist leaf-mining moth. J. Anim. Ecol. 77: 757-767.

276 HANSKI, I. 1994. A practical model of metapopulation dynamics. J. Anim. Ecol. 63:151-162.

277 Harms, K. E., S. J. Wright, O. Calderon, A. HernandeZ, ANd E. A. Herre. 2000. Pervasive 278 density-dependent recruitment enhances seedling diversity in a tropical forest. Nature $279 \quad 404: 493-495$. 
Hosaka, T., T. Yumoto, Y. Chen, I. Sun, S. J. Wright, AND MD. N. NoOR (2011). Abundance of insect seed predators and intensity of seed predation on Shorea (Dipterocarpaceae) in two consecutive masting events in Peninsular Malaysia. J. Trop. Ecol. 27: 651-655.

Jansen, P. A., S. A. Bohlman, C. X. Garzon-Lopez, H. OlfF, H. C. Muller-LandaU, And S. J. WRIGHT. 2008. Large-scale spatial variation in palm fruit abundance across a tropical moist forest estimated from high-resolution aerial photographs. Ecography 31: 33-42.

JANZEN, D. H. 1970. Herbivores and the number of tree species in tropical forests. Am. Nat. 104: 501-528.

JANZEN, D. H. 1980. Specificity of seed-attacking beetles in a Costa Rican deciduous forest. J. Ecol. 68: 929-952.

JONES, F. A., AND L. S. COMITA. 2010. Density-dependent pre-dispersal seed predation and fruit set in a tropical tree. Oikos 119: 1841-1847.

292 Jeffs, C. T., P. Kennedy, P. GRiffith, S. GRiPenberg, L. MARkesteijn, And O. T. LeWis. 2018. Seed predation by insects across a tropical forest precipitation gradient. In press, Ecol.

295 Leigh Jr, E. G., P. Davidar, C. W. Dick, J.-P. Puyravaud, J. Terborgh, H. ter SteEge, AND S. J. WRIGHT. 2004. Why do some tropical forests have so many species of trees? Biotropica 36: 447-473.

298 LoudA, S. M. 1982. Limitation of the recruitment of the shrub Haplopappus squarrosus

299 (Asteraceae) by flower- and seed-feeding insects. J. Ecol. 70: 43-53.

300 Mangan, S. A., S. A. Schnitzer, E. A. Herre, K. M. Mack, M. C. Valencia, E. I. Sanchez, 301 AND J. D. BEVER. 2010. Negative plant-soil feedback predicts tree-species relative 302 abundance in a tropical forest. Nature 466: 752-755. 
Nakagawa, M., T. Itioka, K. Momose, T. Yumoto, F. Komai, K. Morimoto, B. H. Jordal, M. Kato, H. Kaliang, A. A. Hamid, T. InOUe, AND T. NAKAShizuKa. 2003. Resource use of insect seed predators during general flowering and seeding events in a Bornean dipterocarp rain forest. Bull. Ent. Res. 93: 455-466.

Nakagawa, M., Y. Takeuchi, T. Kenta, And T. NAKashizuKa. 2005. Predispersal seed predation by insects vs. vertebrates in six Dipterocarp species in Sarawak, Malaysia. Biotropica 37: 389-396.

Novotny, V., S. E. Miller, L. Baje, S. Balagawi, Y. Basset, L. CizeK, K. J. Craft, F. Dem,

PARKER, G. F., SMith, A. P., AND Hogan, K. P. 1992. Access to the upper forest canopy with a R. A. I. Drew, J. Hulcr, J. Leps, O. T. Lewis, R. Pokon, A. J. A. Stewart, G. Allan large tower crane. BioScience 42: 664-670.

RAMíReZ, N., AND A. TRAVESET. 2010. Predispersal seed-predation by insects in the Venezuelan mangrove forests: extent and effects on seed viability and the growth of seedlings. NOvOTNY. 2017. Low host specificity and abundance of frugivorous lepidoptera in the lowland rain forests of Papua New Guinea. PLoS ONE 12: e0171843. 
Schnitzer, S. A., S. A. Mangan, J. W. Dalling, C. A. Baldeck, S. P. Hubbell, A. Ledo, H.

327

328

329

330

331

332

333

334

335

336

337

338

339

340

341

342

343

344

345

346

347

348

Muller-Landau, M. F. Tobin, S. Aguilar, AND D. BRASSFIELD. 2012. Liana

abundance, diversity, and distribution on Barro Colorado Island, Panama. PloS ONE 7: e52114.

SCHUPP, E. W. 1992. The Janzen-Connell model for tropical tree diversity: Population implications and the importance of spatial scale. Am. Nat. 140: 526-530.

SEDIO, B. E., AND A. M. OstLING. 2013. How specialised must natural enemies be to facilitate coexistence among plants? Ecol. Lett. 16: 995-1003.

SousA, W. P., P. G. KenNedy, AND B. J. Mitchell. 2003. Propagule size and predispersal damage by insects affect establishment and early growth of mangrove seedlings. Oecologia 135: 564-575.

STUMP, S. M. AND P. ChesSON. 2015. Distance-responsive predation is not necessary for the Janzen-Connell hypothesis. Theor. Pop. Biol. 106: 60-70.

Tack, A. J. M., O. Ovaskainen, P. PULKKINEN, AND T. Roslin. 2010. Spatial location dominates over host plant genotype in structuring an herbivore community. Ecology 91: 2660-2672.

VAlenCia, R., H. BALSLEV, AND G. PAZ Y Miño C. 1994. High tree alpha-diversity in Amazonian Ecuador. Biodivers. Conserv. 3: 21-28.

VisSER, M. D., H. C. Muller-LANDAU, S. J. Wright, G. RutTen, AND P. A. JANSEN. 2011. Tritrophic interactions affect density dependence of seed fate in a tropical forest palm. Ecol. Lett. 14: 1093-1100.

Wesselingh, R. A., M. WitTeVeldt, J. MoRissette, AND H. C. M. DEN NiJs. 1999. Reproductive ecology of understory species in a tropical montane forest in Costa Rica. Biotropica 31: 637-645. 
349 WRIGHT, J. S. 2002. Plant diversity in tropical forests: a review of mechanisms of species

$350 \quad$ coexistence. Oecologia 130: 1-14.

351 WRIGHT, S. J., AND O. CALDERÓN. 2006. Seasonal, El Niño and longer term changes in flower

352 and seed production in a moist tropical forest. Ecol. Lett. 9: 35-44.

353 XiaO, Z., X. Mi, M. Holyoak, W. XIE, K. CaO, X. Yang, X. Huang, and C. J. Krebs. 2017.

354 Seed-predator satiation and Janzen-Connell effects vary with spatial scales for seed-

355 feeding insects. Annals of Botany 119: 109-116.

356 XU, Y., Z. SHEN, D. LI, AND Q. GUO. 2015. Pre-dispersal seed predation in a species-rich forest

357 community: Patterns and the interplay with determinants. PLoS ONE 10: e0143040.

358

359 
TABLE 1. Summary of data sets on insect seed predation in tropical forest plant communities, as obtained from the literature. Studies

361 were identified using literature searches (Web of Science and Google Scholar; search terms seed predat* AND insect* AND tropic*)

362 and through reference lists of relevant publications. The Google Scholar search yielded a large number of studies. These were sorted

363 according to relevance, and only the top 500 studies were assessed for suitability based on title and/or abstract. Case studies focussing

364 on single plant species were excluded, since the selection of focal species is likely to be biased towards species with particularly high

365 predation rates. In studies denoted with an asterisk $(*)$, the focus was not exclusively on pre-dispersal enemies, although it seems

366 likely (based on sampling methodology and taxa involved) that a substantial proportion of the seed predation will be inflicted by

367 enemies attacking seeds prior to seed dispersal. In most cases, sampling is unlikely to be exhaustive, and more plant-seed predator

368 interactions would likely have been detected had sample sizes been larger. Hence, the values of the number and \% of attacked species

369 reported are likely smaller than true values.

370

\begin{tabular}{|c|c|c|c|c|c|c|c|}
\hline Source & $\begin{array}{l}\text { Focal seed predator } \\
\text { group }\end{array}$ & $\begin{array}{l}\text { Geographical } \\
\text { region }\end{array}$ & $\begin{array}{l}\text { Method used to } \\
\text { assess incidence } \\
\text { and rates of seed } \\
\text { predation }\end{array}$ & $\begin{array}{l}\text { Type of seeds examined } \\
\text { (mature or immature) }\end{array}$ & $\begin{array}{l}\text { Number of } \\
\text { plant species } \\
\text { studied }\end{array}$ & $\begin{array}{l}\text { Number (and } \\
\% \text { ) of plant } \\
\text { species } \\
\text { attacked }\end{array}$ & $\begin{array}{l}\text { Proportion of } \\
\text { seeds attacked } \\
\text { per plant species } \\
(\text { min-max) }\end{array}$ \\
\hline $\begin{array}{l}\text { *Basset et al. } \\
2018\end{array}$ & $\begin{array}{l}\text { All internally } \\
\text { feeding seed } \\
\text { predators }\end{array}$ & $\begin{array}{l}\text { Lowland } \\
\text { rainforests of } \\
\text { Panama (Barro } \\
\text { Colorado Island) }\end{array}$ & $\begin{array}{l}\text { Rearing of } \\
\text { internally feeding } \\
\text { insect seed } \\
\text { predators }\end{array}$ & $\begin{array}{l}\text { Freshly fallen mature and } \\
\text { immature fruits and seeds } \\
\text { collected mostly from the } \\
\text { ground }\end{array}$ & $497^{b}$ & $319(64.2 \%)^{\mathbf{b}}$ & Not reported \\
\hline $\begin{array}{l}\text { *Basset et al. } \\
2018\end{array}$ & $\begin{array}{l}\text { All internally } \\
\text { feeding seed } \\
\text { predators }\end{array}$ & $\begin{array}{l}\text { Southern Thailand } \\
\text { (forests } \\
\text { surrounding the } \\
\text { 24-ha ForestGEO } \\
\text { plot in Khao } \\
\text { Chong) }\end{array}$ & $\begin{array}{l}\text { Rearing of } \\
\text { internally feeding } \\
\text { insect seed } \\
\text { predators }\end{array}$ & $\begin{array}{l}\text { Freshly fallen mature and } \\
\text { immature fruits and seeds } \\
\text { collected mostly from the } \\
\text { ground }\end{array}$ & $357^{\mathbf{b}}$ & $255(71.4 \%)^{\mathbf{b}}$ & Not reported \\
\hline
\end{tabular}




$\begin{array}{ll}* \text { Basset } \text { et al. } & \begin{array}{l}\text { All internally } \\ \text { feeding seed } \\ 2018\end{array} \\ & \text { predators }\end{array}$

Beckman \&

Muller-Landau

2011 $\begin{array}{ll}* \text { Ctvrtecka } \text { et al. } & \text { Internally feeding } \\ 2014 & \text { Curculionidae }\end{array}$

Curculionidae

All insect seed predators

$\begin{array}{ll}\text { Greig } 1993 & \begin{array}{l}\text { All insect seed } \\ \text { predators (main taxa }\end{array} \\ & \begin{array}{l}\text { Hemiptera and } \\ \text { Coleoptera); most } \\ \text { seed predators likely } \\ \text { to be external } \\ \text { feeders }\end{array} \\ & \begin{array}{l}\text { All internally } \\ \text { feeding seed } \\ \text { predators }\end{array} \\ & \text { Hosaka } \text { et al. }\end{array}$

Lowland

rainforests of

Papua New

Guinea (seed and

fruit samples

collected in and

around the

ForestGEO 50-ha

forest dynamics

plot in Wanang)

Dry, semi-

deciduous forest

in Panama (Parque

Metropolitano)

Lowland

rainforests of

Papua New

Guinea (two sites

in the Madang

province)

Lowland

rainforests of

Costa Rica (La

Selva)

Insecticide

application

Rearing of

internally feeding

insect seed

predators

\section{Experimental}

seed predators:

infrutescences

monitored

throughout

development

Dipterocarp forest,

Pasoh forest

reserve, Malaysia

\section{Rearing of}

internally feeding

insect seed
Freshly fallen mature and

mmature fruits and seeds collected mostly from the ground

Mature and immature

Mature or nearly mature fruits; pre- and post-

dispersal

predators; seed

dissections
Fruiting season 1: $0.27-0.34$

Fruiting season 2: 0.35-0.49 


\begin{tabular}{|c|c|c|c|c|c|c|c|}
\hline *Janzen 1980 & $\begin{array}{l}\text { Internally feeding } \\
\text { beetles (primarily } \\
\text { bruchids) }\end{array}$ & $\begin{array}{l}\text { Lowland dry } \\
\text { forests of Costa } \\
\text { Rica }\end{array}$ & $\begin{array}{l}\text { Rearing of } \\
\text { internally feeding } \\
\text { insect seed } \\
\text { predators }\end{array}$ & $\begin{array}{l}\text { Ripe or nearly ripe seeds } \\
\text { and fruits; collected from } \\
\text { parent plant or ground } \\
\text { below it }\end{array}$ & $\sim 975$ & $110(\sim 8.9 \%)$ & Not reported \\
\hline $\begin{array}{l}\text { *Jeffs et al. } \\
2018\end{array}$ & $\begin{array}{l}\text { All internally } \\
\text { feeding seed } \\
\text { predators } \\
\text { (Coleoptera, } \\
\text { Lepidoptera, } \\
\text { Diptera) }\end{array}$ & $\begin{array}{l}\text { Lowland forests of } \\
\text { Panama ( } 8 \text { sites) }\end{array}$ & $\begin{array}{l}\text { Visual } \\
\text { examination of } \\
\text { dissected seed } \\
\text { samples }\end{array}$ & $\begin{array}{l}\text { Freshly fallen mature and } \\
\text { immature fruits and seeds } \\
\text { collected from the ground }\end{array}$ & 34 & $15(44 \%)$ & $0.018-1^{\mathbf{h}}$ \\
\hline $\begin{array}{l}\text { Nakagawa et al. } \\
2003\end{array}$ & $\begin{array}{l}\text { Internally feeding } \\
\text { seed predators } \\
\text { (Lepidoptera, } \\
\text { Coleoptera) }\end{array}$ & $\begin{array}{l}\text { Tropical lowland } \\
\text { forest in Lambir } \\
\text { Hills, Malaysia }\end{array}$ & $\begin{array}{l}\text { Rearing of } \\
\text { internally feeding } \\
\text { insect seed } \\
\text { predators }\end{array}$ & $\begin{array}{l}\text { Seeds collected from seed } \\
\text { traps. Maturity stage not } \\
\text { mentioned, but likely } \\
\text { mature or close to } \\
\text { maturity. }\end{array}$ & $\begin{array}{l}\text { 1996: } 26 \\
\text { 1998: } 15\end{array}$ & $\begin{array}{l}\text { 1996: } 25 \\
(96.2 \%) \\
1998: 13 \\
(86.7 \%)\end{array}$ & $\begin{array}{l}\text { 1996: } 0.007-0.143^{\mathrm{i}} \\
\text { 1998: } 0.002-0.492^{\mathrm{j}}\end{array}$ \\
\hline $\begin{array}{l}\text { Nakagawa et al. } \\
2005\end{array}$ & $\begin{array}{l}\text { Internally feeding } \\
\text { insect seed predators }\end{array}$ & $\begin{array}{l}\text { Tropical lowland } \\
\text { forest in Lambir } \\
\text { Hills, Malaysia }\end{array}$ & $\begin{array}{l}\text { Rearing of } \\
\text { internally feeding } \\
\text { seed predators }+ \\
\text { examination of } \\
\text { dissected seeds }\end{array}$ & $\begin{array}{l}\text { Freshly fallen immature } \\
\text { and mature seeds and fruits } \\
\text { collected from seed traps. }\end{array}$ & 6 & $6(100 \%)$ & $0.235-0.784^{1}$ \\
\hline $\begin{array}{l}\text { Ramirez \& } \\
\text { Traveset } 2010\end{array}$ & $\begin{array}{l}\text { All internally } \\
\text { feeding insect seed } \\
\text { predators }\end{array}$ & $\begin{array}{l}\text { Venezuelan } \\
\text { Central Plain (not } \\
\text { only forest } \\
\text { habitats) }\end{array}$ & $\begin{array}{l}\text { Rearing of } \\
\text { internally feeding } \\
\text { seed predators }\end{array}$ & $\begin{array}{l}\text { Seeds ready or nearly } \\
\text { ready for dispersal; } \\
\text { samples taken directly } \\
\text { from the parent plant }\end{array}$ & 187 & $89(47.6 \%)$ & Not reported \\
\hline $\begin{array}{l}* \text { Robertson et } \\
\text { al. } 1990\end{array}$ & $\begin{array}{l}\text { All seed-boring } \\
\text { insects (Coleoptera, } \\
\text { Lepidoptera, } \\
\text { Diptera, } \\
\text { Hymenoptera) }\end{array}$ & $\begin{array}{l}\text { Mangrove forests } \\
\text { at } 12 \text { sites in } \\
\text { tropical } \\
\text { Queensland, } \\
\text { Australia }\end{array}$ & $\begin{array}{l}\text { Propagules scored } \\
\text { for signs of insect } \\
\text { attack (holes, } \\
\text { feeding tracks) }\end{array}$ & $\begin{array}{l}\text { Mostly fallen propagules; } \\
\text { for some tree species seeds } \\
\text { also collected from the } \\
\text { plant }\end{array}$ & 12 & $12(100 \%)$ & $0.062-0.803^{\mathrm{m}}$ \\
\hline $\begin{array}{l}\text { *Sam et al. } \\
2017\end{array}$ & & $\begin{array}{l}\text { Lowland } \\
\text { rainforests of } \\
\text { Papua New } \\
\text { Guinea (two sites }\end{array}$ & $\begin{array}{l}\text { Rearing of } \\
\text { internally feeding } \\
\text { seed- and fruit- } \\
\text { associated } \\
\text { Lepidoptera }\end{array}$ & $\begin{array}{l}\text { Mature or nearly mature } \\
\text { fruits; pre- and post- } \\
\text { dispersal }\end{array}$ & $326^{d}$ & $171(52.5 \%)$ & Not reported ${ }^{\mathbf{n}}$ \\
\hline
\end{tabular}


in the Madang

province)

\begin{tabular}{|c|c|c|c|c|c|c|c|}
\hline $\begin{array}{l}\text { Wesselingh et } \\
\text { al. } 1999\end{array}$ & $\begin{array}{l}\text { Internally feeding } \\
\text { seed predators } \\
\text { (Hymenoptera, } \\
\text { weevils) }\end{array}$ & $\begin{array}{l}\text { Two sites in } \\
\text { tropical montane } \\
\text { forest in Costa } \\
\text { Rica (Cordillera } \\
\text { de Talamanca) }\end{array}$ & $\begin{array}{l}\text { Visual } \\
\text { examination of } \\
\text { seeds }\end{array}$ & Mature seeds & 4 & $4(100 \%)$ & $0.082-0.560^{\circ}$ \\
\hline Xu et al. 2015 & $\begin{array}{l}\text { All pre-dispersal } \\
\text { seed predators } \\
\text { (insects and } \\
\text { vertebrates) leaving } \\
\text { feeding marks on } \\
\text { seeds. }\end{array}$ & $\begin{array}{l}\text { Mixed evergreen- } \\
\text { deciduous } \\
\text { broadleaf forest in } \\
\text { subtropical China } \\
\text { (Dalaoling Nature } \\
\text { Reserve, Hubei } \\
\text { Province) }\end{array}$ & $\begin{array}{l}\text { Visual } \\
\text { examination of } \\
\text { seed samples }\end{array}$ & $\begin{array}{l}\text { Seeds at different stages of } \\
\text { maturity collected from } \\
\text { traps }\end{array}$ & 44 & $17(38.6 \%)$ & $0.002-0.556^{\mathbf{p}}$ \\
\hline
\end{tabular}

ancludes only the subset of plant species attacked by insect seed predators.

${ }^{b}$ Data obtained from lead author.

'Table A1 in Ecological Archives E092-185-A1

$375{ }^{\mathrm{d} C}$ Considering only species with samples comprising min 50 fruits weighing min $1 \mathrm{~kg}$.

376 eNot reported, but likely to be low. ["(...) one weevil per 33 individual fruits on average"]

377 Seed predation rates reported in Table 3.

378 gSeven species included in study, but intensity of seed predation only recorded for three.

379 heed predation rates reported in Table 2. Inga sp. excluded, and only one entry for Oenocarpus mapora.

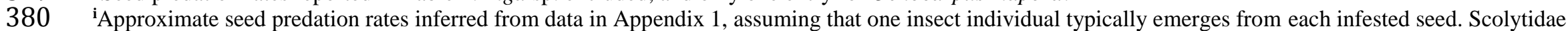

381 excluded when estimating proportion of seeds attacked, since for this taxon multiple individuals often emerge from each infested seed (pers. obs.).

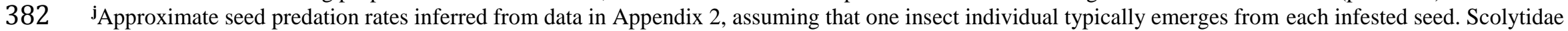

excluded when estimating proportion of seeds attacked, since for this taxon multiple individuals often emerge from each infested seed (pers. obs.).

384 kPredation rates reported only for mature seeds (but acknowledged in the source article that immature fruits were also commonly attacked by insects).

385 'Seed predation rates reported in Table 2

386 meed predation rates reported in Table 1. Species-specific means obtained by pooling data from different sites.

"Not reported, but likely to be low ["(...) low incidence of seed damage"] 